\title{
A Comparative Analysis of the Impact of the Fixed and Flexible Exchange Rate Systems on the Nigerian Economy
}

\author{
${ }^{1}$ Ajekwe, Tagher, ${ }^{2}$ Korna, Johnmark M, ${ }^{3}$ Idyu, Isaac A. \\ ${ }^{1}$ Lecturer II, Accounting and Finance Department University of Agriculture Makurdi, Benue State, Nigeria. \\ ${ }^{2}$ Research Fellow, Banking and Finance Department, University of Nigeria Nsukka, Nigeria. \\ ${ }^{3}$ Research Fellow, Banking and Finance Department, University of Nigeria Nsukka, Nigeria.
}

\begin{abstract}
This study was conducted with the objective of comparing the impact of the fixed and flexible exchange rate systems on the Nigerian economy from (1960-2007). This period has been split into two, namely the period of the fixed exchange rate system (1960-1985) and the period of the flexible exchange rate system (1986-2007). The impact of these two exchange rate systems on Gross Domestic Product (GDP) and Balance of Payments (BOP) which have been taken to represent the economy has been the focus of this study. The methodology adopted for this study has been the ex post facto research design which enabled the researcher makes use of secondary data on GDP and Balance of Payments for the period to test the four hypotheses stated in this study. The researcher made use of the Ordinary Square Least (OLS) method otherwise known as the simple regression technique through the use of the Statistical Package for Social Science (SPSS) to analyze the data. Results show that the fixed exchange rate system has had a significant positive impact on GDP (Coefficient of NER $=92298.711, t_{c}=5.124$ ) and an insignificant but positive impact on balance of payments (Coefficient of NER $\left.=279.119, t_{c}=0.208\right)$. The flexible exchange rate system on the other hand, has had a significant positive impact on GDP (Coefficient of NER $=94681.107, t_{c}=6.624$ ) and a insignificant negative impact on balance of payments (Coefficient of NER $=-2916.052, t_{c}=-0.816$ ). It has been recommended that the present system of flexible exchange rates should be fine-tuned to allow for some form of government intervention in fixing exchange rates when the need arises. Another recommendation is that the government should adopt a policy of import-substitution to conserve the scarce foreign reserves so as to help improve balance of payments position among other recommendations.
\end{abstract}

\subsection{Background of the Study}

\section{Introduction}

International trade arose as a result of differences in resource endowment among nations. While some nations have more than they need, others do not have. In addition, while some nations are very efficient in the production of some goods. Others are less so. These problems have been reconciled through international trade. That is, it is anchored on comparative advantage in production and gains from trade as well as specialisation. Through trade (and international trade in particular), nations can now purchase those goods they need but which they cannot produce, for one reason or another while exporting those they can produce in abundance to other countries. To import what a nation needs will involve payment for that item in foreign currency, this being the major difference between home trade and foreign trade which is otherwise known as international trade.

This necessarily involves the determination of the rate at which the home currency of the importer will exchange for that of the exporter's for instance, if a Nigerian buys goods from a seller in Belgium, the problem of foreign exchange is involved. The buyer would want to make payment in naira, but the seller would like to be paid in the Belgian franc. Another problem would be how much naira would be exchanged for the Belgian franc? That is there will be need to determine the rate of exchange between the two currencies involved. That rate at which one national currency exchanges for another in the foreign exchange market is known as the exchange rate of the currency in question. The foreign exchange market by definition is that international market in which one national currency can be exchanged for another.

Two exchange rate systems are identifiable, namely, the fixed exchange rate and the floating of flexible (fluctuating) exchange rates. In a fixed exchange rate regime, national governments agree to maintain the convertibility of their currencies at a fixed exchange rate. Under a regime of fixed exchange rate, governments are committed to intervention in the foreign exchange market to maintain nominal exchange rate (Begg, et al, 1984). In a floating (flexible) exchange rate regime, the exchange rate is allowed to attain its free market equilibrium level without any government intervention through transaction that increase or reduce the foreign exchange reserves (Begg et al 1984). That is, the forces of demand and supply are allowed to establish the exchange rate of one currency against another.

In practice, only very few countries do permit the value of their national currencies to be determined by the interaction of the forces of demand and supply. Thus, throughout the $19^{\text {th }}$ and $20^{\text {th }}$ centuries, countries have 
sought to maintain a pattern of relatively fixed exchange rates. The gold standard and the gold-exchange standard (Bretton woods system) both of which were fixed had been based on the when international currency values are kept as stable as possible by government intervention in exchanges markets. (O'connor and Buesco 1990).

According to Ammer and Ammer (1984) from the end of World War I until 1971, the major trading nations preferred a fixed rate of exchange, with each country setting a par value for its currency (known as the official rate)". They further observed that in practice, this rate varied slightly. Before World War II, the par value of each major currency normally was fixed in relation to gold; in the post war period, it was set (by the International Monetary Fund) in relation to the U.S. dollar, which was itself tied to gold (the U.S Treasury was by law committed to buying gold at fixed price of $\$ 35$ per ounce (Ammer. 1984)

However, in 1971, the U.S. government suspended the convertibility of the (U.S) dollar owing to the serious balance of payments deficit it had (Ammer and Ammer 1984). The result of this was that the dollar could no longer be freely exchanged for gold at a fixed price with the absence of a single stable currency unit, exchange rate then floated (fluctuated), based largely on the forces of demand and supply. But also the U.S. dollar as an international convertible currency led to the collapse of the fixed exchange rate system. With the collapse of Bretton woods system of fixed exchange system, attention shifted to the floating or flexible exchange rate system.

The members of the International Monetary Fund (IMF) who had hoped to devise some kind of stable system of currency valuation to replace fixed par values, agreed in Mid-1974 to continue to operate a managed floating rate, that is, a floating rate influenced by individual governments trading in their own currencies (pegging) in order to stabilise its market (but not imposing other, more restrictive exchange controls).

For a country like Nigeria that is heavily dependent on imports, and that has only one major source of earning foreign exchange namely, oil, interest in what constitutes an acceptable exchange rate system becomes crucial as the exchange rate has a crucial role to play in the balance of payments position of a country. The balance of payments is a measure of receipts from exports and expenditure on imports of goods and services over a given period of time usually a year. It could be favourable, meaning an excess of receipts over payments; or it could be unfavourable (deficit), meaning more payment (on imports) than receipts (from exports). The balance of payments position or the maintenance of external equilibrium is a major preoccupation of all nations.

As a member of the international community, Nigeria too has been following emerging trends in the international financial arena. Because its economy is linked to the international economic system, the country has to adjust in keeping with the mood in the international financial system. Recently, the world economy had serious problems, most countries experienced balance of payments problems, the result of fundamental problems in their national or domestic economies. Most of such countries instituted policy prescriptions recommended by the International Monetary Fund, aimed at correcting the structural defects inherent in their economies. The structural adjustment programme is one of such policies adopted, especially in the developing countries, Nigeria being one of them.

Liberalization of exchange rates was one of the objectives of the structural Adjustment programme (SAP). Accordingly, the country adopted a system of floating exchange rates, allowing the naira to find a realistic exchange rate (value) against other currencies based on the interactions of demand and supply in the foreign exchange market. However, this failed to improve the economic fortunes of the country as the balance of payment problems persisted, if not worsened.

During the 1994 fiscal year, the Head of the State, in his budget speech announced that the exchange rate of the naira had been fixed at N22 to $\$ 1$ (one) U.S. dollar. The implication of this is that the floating exchange rate system of the structural adjustment years had been abandoned, and a system of fixed or pegged exchange rates instituted. However, following the emergence of Civil Rule from 1999 to date, attempts have been made to liberalise the economy with several policy measures such as the privatisation and commercialisation of Public Enterprises and the National Economic Empowerment and Development Strategy. These policy documents introduced several other changes to the economy including exchange rate policies.

This study therefore, is an attempt to look at the fixed (pegged) exchange rate system, and the floating or flexible exchange rate system in terms of their advantages and disadvantages, and hence the desirability of one over the other. In other words, this study would consider what impact fixed and flexible exchange rates have had on the Nigerian economy over the years. Their impact on Balance of Payments and Gross Domestic Product (GDP) would be the main focus

\subsection{Statement Of The Problem}

The Nigerian economy is characterised by heavy dependence on imports and an over reliance on a single product as the main source of foreign exchange earnings. Ours is an import-oriented economy we import virtually everything from raw materials to finished products. This constitutes a drain on our foreign reserves with serious implications on the badly needed foreign exchange. Here in lies the problem of our study. 
The result of this has been that, over the years, we have had a persistent balance of payments problem. That is, the value of our imports has always exceeded the value of our exports.

The price of our main foreign exchange earner oil is determined independently of us, and moreover, the world market for oil has suffered a glut (excess supply) and the price has dropped sharply without any sign of recovery in sight. This has improved in recent years though!

With a persistent balance of payments problem, the question then arises, what is the way out of this quagmire? One option seems to be a re-examination of the exchange rate system presently is use.

Stated simply the problem under study borders on what impact the adoption of a particular foreign exchange rate system has on the balance of payments position of the country and on the Gross Domestic Product (GDP)

\subsection{Research Questions}

The research questions for this study are as follows:

I) What impact does the fixed exchange rate system have on the Nigerian economy especially on GDP and balance of payments during the period under review (1960-1985)?

II) What impact does the flexible exchange rate system (regime) have on the Nigerian economy in general especially on GDP and balance of payment during the period under review (1986-2007)?

\subsection{Objectives Of The Study}

The research work has the following objectives

i) To determine what impact the fixed exchange rate system has had on the Nigerian economy especially on GDP and balance of payments during the period (1960 - 1985).

ii) To determine what impact the flexible exchange rate system has had on the Nigerian economy especially on GDP and balance of payments during the period (1986 - 2007).

\subsection{Hypotheses Of The Study}

The hypotheses to be tested in this research which are stated in null form include the following:

$\mathrm{H}_{0}$ : The fixed exchange rate system does not have a positive impact on gross domestic product (i.e the economy).

$\mathrm{H}_{0}$ : The fixed exchange rate system does not have a

positive impact on balance of payments (BOP) (i.e the

$\mathrm{H}_{\mathrm{O}}$ : The flexible exchange rate system does not have a impact on gross domestic product (GDP), (ie the

$\begin{array}{ll}\text { economy). } & \text { significant } \\ & \text { positive }\end{array}$

economy),

$\mathrm{H}_{0}$ : The flexible exchange rate system does not have a positive impact on balance of payments (BOP).

\subsection{Scope Of The Research}

The research covers the period from 1960 to 2007 for which data is available on the topic. This period covers two distinct phases during which the Nigerian government experimented with both fixed and flexible exchange rate systems.

\subsection{Key Words:}

a. Exchange Rate-the value of one currency in terms of another currency or other currencies. For example, the value Nigeria $(\mathrm{N})$ against the United States dollar (\$) constitutes the exchange rate between the two currencies.

b. Exchange Rate System (or Regime)- this is an exchange rate mechanism or option adopted by nations in their conduct of international trade and the settlement of other international obligations among themselves. Two exchange rate systems or regimes were in use, namely fixed and flexible exchange rates. There are the variants of these two exchange are system (such as Dirty-float or Managed-floating rates etc).

c. Fixed Exchange Rate System-this is an exchange rate system in which governments do fix or peg the rate of exchange between one national currency and other currencies.

d. Flexible Exchange System-this is an exchange rate system in which the exchange rate between currencies is not fixed by government but is determined by the interaction of market forces of the demand for and supply of currencies.

e. Balance of Payments (BOP)-this is a measure of the difference the value of a country's exports and imports of goods and services over a given period of time, usually one year.

f. Gross Domestic product (GDP)-this measures the value of goods and services produced is an economy over a given period. It is thus a measure of domestic production by an economy. 
g. Privatisation and Commercialisation-this is a government policy of divesting itself of participation in the running and funding of Public Enterprises which were hitherto being run and funded by the government. These enterprise had a dwindling effect on government revenues and it became impossible for government to continue supporting them and hence the need to sell off some (privatisation) an commercialise some (run them as profit-making enterprises).

h. NER(FXD) - naira exchange rate under the fixed exchange rate system

i. NER(FLEX)- naira exchange rate under the flexible exchange rate system.

\section{Chapter Two: Review Of Related Literature}

\section{Theoretical Review}

In order to be able to address the problem under study, that is, undertaking an analysis of the exchange rate systems, it is necessary to take a brief look at the foreign exchange market. The logic for this is that, it is in this market that the rate of exchange or price of one national currency is determined against another.

In addition, a proper analysis of an exchange rate system adopted by a country, can only be done in relation to the foreign exchange market for it is in this market that such an exchange rate system would find application.

\subsubsection{The Foreign Exchange Market}

Then foreign exchange market is a market in which currencies of different countries could be bought and sold. People need foreign exchange in order to meet their international obligations. This situation results from the fact that international trade involves the use of different currencies.

The Nigerian who wants to purchase a car from a company in the United States cannot pay for that car in naira since the Nigerian naira is not legal tender in the United States. He will therefore have to pay for that car in the U. S. dollar. The foreign exchange market therefore provides the forum whereby the Nigerian importer would obtain exchange (foreign money, dollars in this case) to pay for what he wants to import from the United States.

The price at which the Nigerian naira exchanges for the U. S. dollar in the foreign exchange market is known as the exchange rate, and can be determined through the interaction of demand and supply or through the physical intervention of government (monetary authorities) by arbitrarily fixing the rate at which one currency exchanges for another or others.

For instance, Nigeria had in the past fixed or pegged the exchange rate of the naira at $\$ 22$ to $\$ 1$ (one US dollar) with effect from January, 1994 (Daily Times, 12.1.1994). The foregoing analysis is not restricted to the dollar or naira; it can be extended to any other currency such as the German Mark, Italian Lira, Dutch Guilder etc. Any currency could be bought and sold on the international foreign exchange market.

Participants in the foreign exchange market include individuals, international investors, importers and exporters, international corporations, financial institutions, especially commercial banks, and central banks. The foreign exchange market is primarily an over the counter market linked by telecommunication equipment such as telephones, telexes and computers.

The foreign exchange market is said to have some unique features which include the following:

(i) "Governments are usually heavily involved in price setting especially in trying to set limits on changes in currency price.

(ii) The existence of a well-developed forward market in which people make contracts for future deliveries of a particular currency at an agreed upon price.

(iii) The market (foreign exchange) has some important macro-economic implications. That is, what happens in the foreign exchange market can have substantial effects on (and in turn affected by) interest rates, output and price levels:" (Amacher, and Ulbrich 1986, p. 412).

(iv) Another feature of the foreign exchange market is the existence of a spot market in which transactions in foreign exchange are settled on the spot (Aliber, 1989).

\subsubsection{Exchange Rate System}

Earlier, we defined the exchange rate as being the price or rate at which one national currency can be exchanged for another in the foreign exchange market. That is to say, the exchange rate is the value of one currency against another or others or against gold (especially when currency values were linked to gold).

An exchange rate system or regime is a description of the conditions under which national governments allow exchange rates to be determined (Begg, 1984). The exchange rate system adopted by a country determines the latitude with which those operators on the foreign exchange market can operate. 
Interest in what exchange rate system to adopt stems from the fact that knowledge about alternative exchange rate systems enables a country to know which one is best in terms of meeting such goals as domestic output and employment and the achievement of equilibrium in the balance of payments position.

There are basically two exchange rate systems although each has a number of variations. The two basic exchange rate systems are fixed (or pegged) exchange rate system and flexible (or floating or fluctuating) exchange rate system.

\subsubsection{The Fixed Exchange Rate System}

Truett and Truett (1987) have defined a fixed exchange rate system in this way: "In a fixed rate system, the foreign exchange market is characterized by Government intervention to keep the rate of exchange between currencies stable." In a fixed exchange rate system, national governments agree to maintain the convertibility of their national currencies at a fixed exchange rate. Governments thus intervene in the foreign exchange market to maintain a nominal exchange rate.

Two exchange rate systems both of which have now been abandoned will be considered here, both operated as fixed exchange rates before their abandonment. These are the Gold standard and the Bretton Woods Standard (or the gold - standard).

\subsubsection{Flexible (Floating) Exchange Rate System)}

The problems that led to the failure of the Bretton woods system have prompted countries to search for an alternative exchange rate system. Since 1973, most industrial countries have adopted a system of floating or flexible exchange rates. In a flexible or floating exchange rate regime, the exchange rate is allowed to attain is free market equilibrium level without any government intervention through transactions that increase or reduce the foreign exchange reserves.

According to Hill (2005), the floating exchange rate regime that followed the collapse of the fixed exchange regime was formalized in January 1976 during the Jamaican meeting of the IMF (International Monetary Fund) members where rules for the International Monetary system in place today were agreed.

The Jamaican meeting revised the IMF's Articles of Agreement to reflect the new reality of floating exchange rates. The main elements of the Jamaican Agreement include the following:

(i) Floating rates were declared acceptable. IMF members were permitted to enter the foreign exchange market to even out "unwarranted" speculative fluctuations.

(ii) Gold was abandoned as a reserve asset. The IMF returned its gold reserves to members at the current market price, placing the proceeds in a trust fund to help poor nations. IMF members were permitted to sell their own gold reserves at the market price.

(iii) Total IMF quotas - the amount member nations contribute to the IMF - were increased to $\$ 41$ billion. These have since then increased to $\$ 280$ billion while the membership of the IMF has expanded to include 184 countries (Hill, 2005 p. 351).

According to Solmon (1980), "under the system of floating exchange rates, the price of one currency in terms of another is determined simply by demand and supply, as exporters and importers compete in the open market to buy currencies they require". The aim of a regime of floating or flexible exchange rates is to solve the problem of an imbalance between exports and imports, by allowing exchange rates to fluctuate freely (Arnold, 2005).

In reality, only few countries if any, do permit the value of their currencies to be determined by the intervention of the forces of demand and supply. There is always some form of interaction by government (or monetary authorities) even in a regime of flexible or floating exchange rates. This is referred to as a dirty float or manage float, which implies that central banks intervene in the foreign exchange market and attempt to affect exchange rates by influencing the supply of and the demand for currencies (O'Connor and Buesco, 1990), (Blanchard, 2006). A country can set a margin within which its currency can fluctuate relative to other countries' currencies, beyond such a margin, the country is bound to intervene to bring the exchange rate to an acceptable level; vis-à-vis other currencies.

\subsubsection{Fixed And Flexible Exchange Rates Compared}

Having considered the various alternative exchange rate systems, it is desirable to consider their merits and demerits in order to be able to say whether one is more appropriate in terms of addressing the balance of payments question of a country, given its level of development.

The advantages or benefits claimed for a system of fixed exchange rates include the following:-

i. That a fixed exchange rate system provides stable exchange rates, which means a fostering of the growth of international trade. This is the major advantage.

ii. It provides a self- adjusting mechanism through which disequilibria in foreign trade are adjusted.

iii. There is no uncertainty regarding prices as the exchange rates are fixed and thus stable 
Fixed exchange rates are thus said to provide monetary discipline, stem speculation in currencies, remove uncertainty regarding future currency moments and lastly provide a trade balance adjustment mechanism (Hill. 2005 Op.cit, p. 355)

Price uncertainly, which inhibits the willingness of investors to make long - term capital investment abroad is another disadvantage.

Finally, floating exchange rates do not ensure the attainment of balance of payments equilibrium.

\subsubsection{Balance Of Payments}

In any discussion of exchange rates, it is necessary to relate this to the balance of payment of a country as the exchange rate has some important role to pay in the determination of a country's balance of payments position. As a result of the forgoing, a brief examination of the concept of balance of payment will be attempted here.

A country's balance of payments has been described by Truett and Truett (1987) as a systematic effort to record the monetary effects of all transactions between its citizens, businesses, and government and those of other countries. Such transaction arise from international trade and investment for services or transfers of income (gifts) A balance of payments is a statement of inflows and outflows of money between one country and other countries of the world over a given period of time, usually a year.

The balance of payments account is made up of three accounts as follows:-

i. A current Account: Covering trade, shipping service transactions, and gifts. The current account records transactions in goods and services on both imports and exports.

ii. A Capital Account: Investments and short-term monetary flows.

iii. An Official Reserves Account: Covering changes in government holdings of foreign exchange, gold, and other international reserves.

A balance of payment may either be favorable (surplus), meaning a net inflow of money, or it may be unfavorable (deficit), meaning net out flow. The overriding goal of most nations is to maintain an equilibrium position in their balance of payments position.

\subsubsection{The Exchange Rate And Balance Of Payments}

The exchange rate by affecting the current account balance and under certain circumstances the capital count balance, affects balance of payment equilibrium. The extent to which the balance of payments will be affected by a change in the exchange rate depends on the price elasticities of both the home demand for imported goods and services, and the foreign demand for the country's exports of goods and services. The greater the various elasticities, the greater the exchange on foreign receipts and expenditures. Ordinarily, the effect of a rise in the exchange rate (e.g. a rise in the exchange of naira against the dollar) is to reduce the Nigerian payment abroad (as imports become dearer and hence little is imported and to increase receipts from abroad as exports become cheaper).

An exchange rate depreciation may sometimes worsen a country's balance of payment if the price elasticities are not sufficiently large. A case of this might be a major exporter of a basic commodity whose price is elastic. This applies to a normal case where exchange depreciation improves the balance of payments. If the country has a freely fluctuating exchange, its balance of payments will always be in equilibrium and any real adjustments that take place will be in terms of trade (i.e. the ratio of the prices of exports to prices of imports). The exchange rate under such a situation will be determined simply by the supply and demand for foreign exchange.

When exchange rates are fixed, disturbances in a nation's balance of payments result in compensatory financing. A deficit is initially financed by a reduction in a nation's international reserves. It may also be controlled by imposition of tariffs on imports to discourage importation. Another way could be through rationing by imposing controls on the import of goods or the export of capital. Another alternative will be to encourage exports or capital inflows by such measures as export subsidies or special inducements to foreign investment in the case of long-term capital movements, or by increasing the domestic rate of interest to encourage short-term capital inflows (Thorn, 1976).

The actual policy adopted will depend on such consideration as its effect on the general level of economic activity and possible effects on particular sectors of the economy. Maintaining or changing the exchange rate will depend on the relative cost involved. If the policies necessary to maintain the existing exchange rate are considered more costly than the effects of depreciation or appreciation, such policies will not be introduced.. 


\section{Empirical Review \\ 2.2.1 Nigerian Foreign Exchange Market Before Structural Adjustment Programme (Sap)}

An analysis of the alterative exchange rate regimes or system as they have been operated in Nigeria can only be attempted after having considered the foreign exchange market in Nigeria for the period to the introduction of the Structural Adjustment Programme (SAP), and during SAP. The way in which the exchange rate was determined under the two periods would also be mentioned. According to Okpara (2006) Nigeria has operated two exchange regimes, fixed exchange regime from 1960 to 1986 and floating exchange rate regime from June 1986 to date.

The foreign exchange market consists of sellers and users or buyers of foreign (money) currency. In Nigeria, the supply of foreign exchange was derived from oil exports, non-oil exports, capital receipts repatriation by Nigerians resident abroad and other invisible receipts by the private sector etc. The demand for foreign exchange on the other hand, reflected payments for imports, external debt service obligations and financial commitments to international organization.

The major participants in the foreign exchange market during this period (pre-SAP) were authorized dealers, the public sector, especially the industrial sector and correspondent banks abroad.

The public sector participants included the Central Bank of Nigeria (CBN). Authorized dealers were banks and other entities granted license or permitted to deal in foreign exchange. (CBN Briefs, August 1993).

During this period, importers and exporters of non-oil commodities were required to get appropriate licenses from the federal ministry of commerce before they could participate in the foreign exchange market.

The authorized dealers needed to pass their application for imports backed by the licenses and other relevant documents to the Central Bank of Nigeria for approval and foreign exchange cover, while depositing the domestic currency equivalent with the Central Bank of Nigeria (CBN) Exporter's applications were similarly routed through authorized dealers to the Central Bank of Nigeria (CBN) and foreign exchange receipt from such transactions were expected to be surrendered to the Bank in exchange for domestic currency (Ibid).

This period was market by the use of form "M", introduced in 1979 when the Comprehensive Import Supervision Scheme (CISS) was put in place to safeguard against such practices as over-invoicing and importation of undeclared items which result in persistent drain on external reserves (Ibid).

The responsibility for authorizing foreign disbursement was shared between the Federal Ministry of Finance and the CBN. The Federal Ministry of Finance had responsibility for public sector applications, while the CBN allocated foreign exchange in respect of private sector applications. In 1984, a reform was made which allowed licensed bank to approve and allocate foreign exchange subject to the maximum allocation made to them by the CBN. This was however discontinued in 1985 due to abuses, and the CBN took over direct allocation of foreign exchange. (CBN Briefs ibid)

\subsubsection{Exchange Rate Determination}

Under the exchange control system (1962-1986) economic objectives played a major role although ad hoc measures were used to determine the Naira exchange rate. The Nigerian currency was pegged to the pound sterling on a 1:1 ratio from 1960 till 1973 when it was devalued by $10 \%$ and allowed to move independently of the sterling.

The Naira after the devaluation was appreciated to source imports cheaply to implement development projects. Between 1981 and 1986, the Naira was again depreciated against either the pound staling or the dollar. Apart from the above, the CBN applied the basket of currencies approach from 1978 as a guide in determining the direction of the exchange rate movement. (CBN Briefs, August, 1993)

It can be deduced from the foregoing that the exchange rate regime in force during this period was the fixed or pegged exchange rate system.

\subsubsection{Foreign Exchange Market In Nigeria Since Sap}

Following the introduction of the Structural Adjustment Programme in July 1986, and in line with the objectives of SAP, the Second-Tier Foreign Exchange Decree was promulgated which established an official First-Tier Foreign Exchange Market (Official Market) and the Second-Tier Foreign Exchange Market (SFEM), which was the commercial market (Mustapha and Fabunmi,1990).

Under the second-tier foreign exchange market, the determination of the Naira exchange rate was made to reflect market forces. That is, the rate of exchange for the Naira was determined by the demand and supply conditions in the open market.

With the introduction of the SFEM, the Federal Ministry of Finance had its allocative powers transferred to the CBN, but it retained approving powers on public sector transactions. Its powers were enhanced in 1989 when it was assigned the responsibility of licensing Bureaux de changes. These bureaux de Changes were set up principally to enlarge the scope of the officially recognized foreign exchange market, 
accord access to small users of foreign exchange in a less formal manner and enhance macro-economic management.

Under the SFEM, the CBN allocated foreign exchange to banks based on individual bank quotas since the inception of SFEM until March, $5^{\text {th }} 1992$ when the system of pre-determined quotas was discontinued. Official funding of the foreign exchange market was suspended on December $15^{\text {th }} 1992$ as a result of the failure to match demand for foreign exchange with the supply of same.

It is worth noting here that the first-tier foreign exchange market and the second-tier exchange market were merged in1987 into an enlarge foreign exchange market (FEM) (CBN Briefs August 1993).

\subsubsection{Exchange Rate Determination And Allocations Of Foreign Exchange Under Sap}

The introduction of SFEM and later FEM (Foreign Exchange Market) signified the adoption of a regime of flexible or floating exchange rates as the exchange rates of the naira was allowed to be determined by the interaction of the of demand and supply. Although these forces were allowed to interact to produce a clearing price as the basis for allocating foreign exchange, the monetary authorities had power to intervene in the market when there was need. Such intervention depended on the state of the balance of payments, the rate of inflation, domestic liquidity and employment situation. Different exchange rate methods were used under the framework of market determined rate of exchange, as follows:

i. The Dual Exchange Rate system: Under this system, there was a first-tier and a second-tier foreign exchange. Debt service payments, expenses of embassies and contributions to international organizations were settled at the first-tier rate. The second-tier rate was determined by auction at the SFEM. The auction made use of different methods such as the average pricing methods, the marginal rates and later the Dutch auction system, was introduced in which individual bank rates were used to allocate foreign exchange up to the marginal rate which cleared the market.

ii. The Unified Exchange Rate System:-

Under this system, following the merging of the first and second-tier markets into FEM (foreign exchange market) and subsequent depreciation of the naira exchanger rate, the inter-Bank market was separated from the official market and an autonomous market for privately sourced foreign exchange emerged with its independent rates. The autonomous market was later merged with FEM. to form the inter-bank foreign exchange market (IFEM)

iii. Completely Deregulated Exchange Rate System

As a result of persistent instability in the foreign exchange market, reflected in the wide divergence of the rate between the official and parallel markets, the CBN adopted a completely deregulated system of foreign exchange trading on March, 51992 (ibid).

Under this system, the CBN bought and sold actively in the market and also supplied in full requests for foreign exchange made by the authorized dealers. The aim was to narrow the parallel market premium and enhance the operational and allocative efficiency of the foreign exchange market.

\subsubsection{Recent Developments in the Foreign Exchange Market.}

Certain developments have taken place in the Nigerian Foreign Exchange Market especially during this era of economic liberalization via privatization and commercialization programmes of the government. These include the following:

i. Inter-Bank Foreign Exchange Market (IFEM). This was started or introduced on $25^{\text {th }}$ October, 1999. Prior to this date all exchanges were AFEM (Autonomous Foreign Exchange Market) rates.

ii. The Dutch Auction system (DAS). This was re-introduced on July 22, 2002 (CBN Statistical Bulletin, December 2005, vol.16)

iii The Wholesale Dutch Auction system (WDAS). This was introduced on February 20, 2006 as an improved framework for determining the exchange rate in the foreign exchange market. Under this arrangement, the CBN remains an active market participant and dealing is based on a two-way quote.

Authorized dealers are required to bid for foreign exchange on their own account and are free to deal with such funds in the inter-bank market. The adoption of the WDAS was to consolidate the gains of the retail DAS (Dutch Auction System), further liberalize the foreign exchange market to enhance its depth, and achieve convergence in rates between the official and other rates.

The introduction of the WDAS led to the appreciation of the average naira exchange rate (at $\$ 128.65$ ) per dollar in 2006 and against ( $\$ 132.05$ ) to the dollar in 2005. (CBN Annual Report and Statement of Account for the year ended $31^{\text {st }}$ December 2006) 


\section{Chapter Three: Methodology \\ IV. Introduction}

This chapter is devoted to the methods for data collection and its subsequent analysis other issues related to data collection and analysis regarding this research work. Details of the sub -topics to be covered in this chapter are considered below.

\subsection{Research Design}

Research design refers to a frame work that guides in the collection and analysis of data. Three types of research designs exist namely; survey, experimental and ex post facto designs. Several methods exist for gathering data and include the following.

i. Exploratory Research, which aims at discovering new ideas and insight about a given phenomenon.

ii. Descriptive Research, which simply describes something or is concerned with the frequency with which something occurs or the relationship between two variables.

iii. Experimental Research, which is concerned with determining the cause and effect relationship in a controlled situation in which all variables are held constant except one. Etc.

For the purpose of this research or study, the descriptive Research Method is the method that has been adopted. The reason is that, the topic is descriptive in nature. It is not meant to discover new ideas nor does it seek to establish cause-effect relationships as is the case with experimental research. This work seeks to describe the relationship that exists between an exchange rate regime and the economy. This research or study also employed the Ex Post Facto research design which is the type of research involving events that have already taken place and for which data already exists, and the research is merely involved in data gathering. Data collection for this study will be from secondary sources, mainly from texts and journals and Central Bank of Nigeria (CBN) publications as well as National Bureau of statistics publications where necessary.

\subsection{Model Specification}

Onwumere (2009) citing the Complete Reference Library, defines a model as "a schematic description of a system, theory, or phenomenon that accounts for its known or inferred properties and may be used for further study of its characteristics" (Onwumere, 2009:28).

A model has also been described as "an abstraction of aspects of reality." Yomere and Agbonifoh cited by Onwumere (2009) consider a model to be "a simplified view of reality designed to enable us describe the essence and inter-relationships within the system or phenomenon it depicts".

A model generally serves to:

i. $\quad$ Guide the researcher in his study

ii. Identify the relevant variables into dependent and independent variables.

iii. Specify the relationships that exist or could exist between these variables.

iv. Enable the researchers formulate and test his hypothesis (Onwumere 2009:28).

For the purpose of this research work, the models specified for consideration are as follows:

i. $\quad$ GDP $=f($ FIXR $)$

ii. $\quad$ GDP $=f(F L X R)$

iii. $\quad \mathrm{BOP}=\mathrm{F}(\mathrm{FIXR})$

iv. $\quad \mathrm{BOP}=\mathrm{f}(\mathrm{FLXR})$

Where

GDP $=$ Gross Domestic product

$\mathrm{BOP}=$ Balance of Payments

FIXR $=$ Fixed Exchange Rate System

FLXR $=$ Flexible Exchange Rate System.

\subsection{Nature And Sources Of Data}

There are basically two main sources of gathering data for research purposes namely; primary data and secondary data. Primary data is data not available It is collected for a given before research effort through questionnaires, interviews etc. Secondary data on the other hand is data already collected or that already exists in published books, journals, report etc.

For the purpose of this research work, secondary data will be heavily relied upon. This is so because the topic under consideration is descriptive in nature, and data already exist on it. Data for this research work will come mainly from materials from textbooks and journals and from the Central Bank of Nigeria (CBN) publication as well as National Bureau of Statistics (NBS) publications and other publications where necessary. 


\subsection{Techniques Of Data Analysis}

Data for this research has been analysed using the Ordinary Least Square (OLS) method or simple regression method through the use of the Statistical Package for Social Science (SPSS) to test hypotheses 1-4.

\subsection{LIMITATIONS OF THE STUDY}

A study of this nature cannot be done without one having a number of limitations or constraints. The fact that even among the experts, the field of international monetary economies and finance is a difficult one is a major constraint or limitation in so far as there is limited literature bearing on this particular topic to bail out the student.

Another constraint has been that of time to do a thorough job searching for all relevant material bearing on this topic. The most obvious of the constraints or limitations is that of finance which is always very hard to get in sufficient amounts.

It is in light of the foregoing limitations and many others not specifically mentioned that any defect in this work should be viewed as having arisen.

\subsection{INTRODUCTION}

\section{Chapter Four: Data Presentation And Analysis}

This chapter is reserved for data presentation and analysis. Accordingly, data for this study has been presented according to the two distinct phases during which Nigeria has experimented with both fixed and flexible exchange rate systems. These two periods are as follows:

i $\quad$ From $1960-1985$ (the period of fixed exchange rate system)

ii From $1986-2007$ (the period of flexible exchange rate system).

Data regarding the behaviour of the naira exchange rate along with the GDP (Gross Domestic Product) and Balance of payments figures for these periods has been presented in Tables $4.1-4.5$ and analyzed.

\subsubsection{Comparative Analysis of the Fixed and Flexible Exchange Rate Systems in Nigeria \\ 4.1.1a Fixed Exchange Rate System (Regime) 1960 - 1985 \\ The various stages or phases of this exchange rate system (or regime) included the following: \\ i) Parity with pond sterling $(1959-1977)$. \\ ii) Pegging against a basket of currencies $(1971-1977)$. \\ iii) The import - weighted basket approach (1978) \\ iv) The US dollar as the currency of intervention (1989). (CBN Briefs, 2009).}

\subsection{1b Flexible Exchange Rate System (Regime) 1986 till date}

The various stages of this exchange rate system included the following:

i) The dual exchange rate system $(1986-1987,1994-1999)$

ii) Guided deregulation period (1995-1998).

iii) Full deregulation under the inter-bank foreign exchange market $(1999-2003)$

iv) The retail Dutch auction system (1987, 1990 and 2002).

v) The wholesale Dutch auction system (2006 - 2008) CBN briefs, 2009).

Under the fixed exchange rate system (or regime), the exchange rate of the national currency

(the Nigerian pound ornaira as the case may be) was fixed against other currencies such as the British pound (in the ratio of 1:1 from 1960 - 1967 and 1:1. 16 from 1968 - 1969) and the United States dollar (in the ratio of 1:2.80 for the same period). From 1970 - 1985 there were relatively small adjustments in exchange rates against these international currencies.

The fixed exchange rate system thus provided stable exchange rates between currencies as witnessed in Nigeria during this period (ie $1960-1985$ ).

The period between $1986-2007$ and beyond has been the period of the flexible for floating exchange rate system (or regime) during which exchange rates between the naira and other currencies such as the united states dollar, the British pound sterling, the euro and other currencies of Nigeria's trading partners have been determined by market forces (of demand and supply of foreign exchange).

This period (1986 -upwards) marked the introduction of the Structural Adjustment Programme (SAP) and its policy prescriptions which were meant to liberalize the economy and give greater freedom to market forces in the determination of the pace of economic activities. This meant that the government had a limited role in the economy. For instance, the government could no longer through the Central Bank of Nigeria (CBN) fix or peg the exchange rate of the naira against other currencies as was the case during the fixed exchange rate regime of the pre-SAP era. This period has therefore provided flexible or fluctuating (or floating) exchange rates which tend to reflect the true value of a currency as against fixed or pegged rates which are arbitrary. The flexible 
exchange rates therefore tend to be favoured more by the industrialized (developed) nations than developing nations (like Nigeria) who rather favour fixed exchange rates.

\subsection{Data Presentation}

Table 4.1GDP (Gross Domestic Product) figures and Exchange Rates under the Fixed Exchange Rate System (1960- 1985)

\begin{tabular}{|c|c|c|}
\hline Year & GDP figures at current basic prices (Million) & $\begin{array}{l}\text { Naira Exchange Rate against the US } \\
\text { dollar }\end{array}$ \\
\hline 1960 & $2,233.0$ & 0.3571 \\
\hline 1961 & $2,361.2$ & 0.3571 \\
\hline 1962 & $2,597.6$ & 0.3571 \\
\hline 1963 & $2,755.8$ & 0.3571 \\
\hline 1964 & $2,894.4$ & 0.3571 \\
\hline 1965 & $3,110.0$ & 0.3571 \\
\hline 1966 & $3,374.8$ & 0.3571 \\
\hline 1967 & $2,752.6$ & 0.3571 \\
\hline 1968 & $2,656.2$ & 0.3079 \\
\hline 1969 & $3,549.3$ & 0.3079 \\
\hline 1970 & $5,281.1$ & 0.7143 \\
\hline 1971 & $6,650.9$ & 0.6955 \\
\hline 1972 & $7,187.5$ & 0.6579 \\
\hline 1973 & $8,630.5$ & 0.6579 \\
\hline 1974 & $18,823.1$ & 0.6299 \\
\hline 1975 & $21,475.2$ & 0.6159 \\
\hline 1976 & $26,655.8$ & 0.6265 \\
\hline 1977 & $31,520.3$ & 0.6466 \\
\hline 1978 & $34,540.1$ & 0.6060 \\
\hline 1979 & $41,974.7$ & 0.5957 \\
\hline 1980 & $49,362.3$ & 0.5464 \\
\hline 1981 & $47,619.7$ & 0.6100 \\
\hline 1982 & $49,069.3$ & 0.6729 \\
\hline 1983 & $53,107.4$ & 0.7241 \\
\hline 1984 & $59,622.5$ & 0.7649 \\
\hline 1985 & $67,908.6$ & 0.8938 \\
\hline
\end{tabular}

Source: CBN statistical Bulletin, December, 2008

Table 4.1 shows data on gross domestic product (GDP) and exchange rates under the fixed exchange rate system from $1960-1985$.

Exchange rates were stable during this period with a 0\% change in exchange rate from $1960-1967$. On the whole, exchange rates were relatively stable during this period.

Table 4.2Balance of payments figures and Exchange rates under the Fixed Exchange Rate System (1960 1985)

\begin{tabular}{|c|c|c|}
\hline Year & Balance of payments (BOP) ( million) & Naira Exchange Rate against the dollar \\
\hline 1960 & 9.2 & 0.3571 \\
\hline 1961 & 4.8 & 0.3571 \\
\hline 1962 & $(3.0)$ & 0.3571 \\
\hline 1963 & $(1.0)$ & 0.3571 \\
\hline 1964 & $(20.6)$ & 0.3571 \\
\hline 1965 & $(4.2)$ & 0.3571 \\
\hline 1966 & $(4.6)$ & 0.3571 \\
\hline 1967 & 46.0 & 0.3571 \\
\hline 1968 & 31.0 & 0.3079 \\
\hline 1969 & 47.8 & 0.3079 \\
\hline 1970 & 46.6 & 0.7143 \\
\hline 1971 & 117.4 & 0.6955 \\
\hline 1972 & 57.2 & 0.6579 \\
\hline 1973 & 197.5 & 0.6579 \\
\hline 1974 & $3,102.2$ & 0.6299 \\
\hline 1975 & 157.5 & 0.6159 \\
\hline 1976 & $(339.0)$ & 0.6265 \\
\hline 1977 & $(527.2)$ & 0.6466 \\
\hline 1978 & $1,293.6$ & 0.6060 \\
\hline 1979 & $1,868.9$ & 0.5957 \\
\hline 1980 & $2,402.2$ & 0.5464 \\
\hline 1981 & $(3,020.8)$ & 0.6100 \\
\hline 1982 & $(1,398.3)$ & 0.6729 \\
\hline 1983 & $(301.3)$ & 0.7241 \\
\hline 1984 & 354.9 & 0.7649 \\
\hline 1985 & 349.1 & 0.8938 \\
\hline
\end{tabular}




\section{Source: CBN statistical bulletin.Vol.16 Dec., 2005}

Table 4.3 shows data on Balance of payments (BOP) and exchange rates under the fixed exchange rate system $(1960-1985)$.

In 10 years out of the 26 years covered by this period, balance of payments figures were in negative (or deficit), positive (surplus) balance of payments figures were however recorded in 16years out of the 26 years during this period. Exchange rates were relatively stable during this period as earlier stated.

Table 4.3: Gross Domestic Product figures and Exchange Rates under the Flexible Exchange Rate system

\begin{tabular}{|c|c|c|}
\hline & & $(1986-2007)$ \\
\hline 1986 & $69,147.0$ & 2.0206 \\
\hline 1988 & $139,085.3$ & 4.5367 \\
\hline 1989 & $216,797.5$ & 7.3916 \\
\hline 1990 & $267,550.0$ & 8.0378 \\
\hline 1993 & $683,869.8$ & 22.9511 \\
\hline 1994 & $899,863.2$ & 21.8861 \\
\hline 1995 & $1,933,211.6$ & 21.8861 \\
\hline 1996 & $2,702,719.1$ & 21.8861 \\
\hline 1997 & $2,801,972.6$ & 21.8861 \\
\hline 2002 & $6,912,381.3$ & 120.9702 \\
\hline 2003 & $8,487,031.6$ & 129.3565 \\
\hline 2004 & $11,411,066.9$ & 133.5004 \\
\hline 2005 & $14,572,239.1$ & 131.6619 \\
\hline 2006 & $18,564,594.7$ & 128.6500 \\
\hline 2007 & $20,657,317.7$ & 124.7600 \\
\hline
\end{tabular}

\section{Source: CBN Statistical Bulletin December 2008.}

Table 4.4 shows the data on gross domestic product during the period of the flexible exchange rate system (1986 - 2007). GDP figures during this period were mostly on the increase.

Exchange rates during this period were not stable except from 1994 to 1998 when the rates were stable at N 21.8861. Exchange rates during this period fluctuated or floated in keeping with the flexible exchange rate regime in which market forces rather than government (through the $\mathrm{CBN}$ ) fixed exchange rates between national currencies.

Table 4.4: Balance of Payments figures and Exchange Rates under the Flexible Exchange Rates System $(1986$ - 2007)

\begin{tabular}{|l|c|c|}
\hline Years & Balance of payments (N millions) & Naira Exchange Rate Against the US dollar \\
\hline 1986 & $(784.3)$ & 2.0206 \\
\hline 1987 & 159.2 & 4.0179 \\
\hline 1988 & $(2,294.1)$ & 4.5367 \\
\hline 1989 & $8,727.8$ & 7.3916 \\
\hline 1990 & $18,498.2$ & 8.0378 \\
\hline 1991 & $5,959.6$ & 9.9095 \\
\hline 1992 & $(65,271.8)$ & 17.2984 \\
\hline 1993 & $13,615.9$ & 22.9511 \\
\hline 1994 & $(42,623.3)$ & 21.8861 \\
\hline 1995 & $(195,316.3)$ & 21.8861 \\
\hline 1996 & $(53,152.0)$ & 21.8861 \\
\hline 1997 & $1,076.3$ & 21.8861 \\
\hline 1998 & $(220,675.1)$ & 21.8861 \\
\hline 1999 & $(326,634.3)$ & 92.6934 \\
\hline 2000 & $314,139.2$ & 92.6934 \\
\hline 2001 & $24,738.7$ & 111.9433 \\
\hline 2002 & $(565,353.3)$ & 120.9702 \\
\hline 2003 & $(162,839.7)$ & 129.3565 \\
\hline 2004 & $1,128,379.4$ & 133.5004 \\
\hline 2005 & $1,364,845.5$ & 131.6619 \\
\hline 2006 & $(1,850,862.16)$ & 128.6500 \\
\hline 2007 & $(3,103,637.93)$ & 124.7600 \\
\hline
\end{tabular}


Source: CBN Statistical Bulletin. Vol. 16, 2005/CBN Annual Reports and Statement of Accounts. Dec., $31^{\text {st }}$ 2007.

Table 4.4 above presents the data on balance of payments (BOP) and exchange rates during the period of the flexible exchange rate system $(1986$ - 2007) covered by this study. This table shows that balance of payments deficits (negative balances) were recorded in 12 years out of the 22 years covered by this study. Positive balance of payments figures (ie surpluses) were however recorded in 10 years out of the 22 years. Exchange rates however fluctuated during this period as stated earlier.

\section{3 data analysis}

\subsubsection{Hypothesis One}

Our hypotheses are stated in both null and alternate forms as follows:

$\mathrm{H}_{0}$ : The fixed exchange rate system does not have a positive impact on gross domestic product (i.e the economy).

$\mathrm{H}_{1}$ : The fixed exchange rate system does have a positive impact on gross domestic product (i.e the economy).

The researcher made use of the ordinary least square (OLS) methodology otherwise known as "Simple Regression method based on the Statistical Package for Social Sciences (SPSS) to test this hypothesis as well as all the other hypotheses in this study.

This simple regression analysis technique (i.e OLS) is used here to establish the impact of the fixed exchange rate system on gross domestic product (GDP) (and by extension on the economy).

\section{Presentation of Empirical Results}

- Estimated Regression Equation (ERE) $=$ GDP $=-28710.779+92298.711$ NER (FXD)

- Student's t-test $\left(\mathrm{t}_{\mathrm{c}}\right)=5.124$ (of NER).

- $\quad$ Standard Error $(\mathrm{S})=15389.184$

- Coefficient of multiple determination $\left(\mathrm{R}^{2}\right)=0.522$

\section{Interpretation of the Results} function.

The equation above $(\mathrm{GDP}=-28710.779+92298.711$ NER $(\mathrm{FXD}))$ shows the estimated regression

The implication of this function is that an increase in the fixed exchange rate[(NER (FXD)] by $1.00 \%$ will lead to a $92298.711 \%$ increase in the gross domestic product (or the economy). The coefficient of multiple determinations $\left(\mathrm{R}^{2}\right)$ shows that $52 \%$ of variations in gross domestic product are explained by changes in the exchange rates (i.e fixed rates).

The coefficient of the fixed exchange rate (NER (FXD) is positively significant as shown by the student's $t_{c}$ value of 5.124. This implies that during this period, the fixed exchange rate system had a significant positive impact on gross domestic product (or the economy). The standard error (S) of 15389.184 also implies that the fixed exchange rate system has had a significant positive impact on gross domestic product (or the economy).

\section{Student's t-test}

The researcher estimated the coefficient of the fixed exchange rate (NER (FXD)) and in the process also calculated the $\mathrm{t}$ statistic of the parameter using t-test with $\mathrm{n}-\mathrm{k}$ degrees of freedom at $5 \%$ level of significance in a two -tailed test.

The number of observations in the sample $(n)=26$

The number of parameter coefficient $(\mathrm{k})=1$

The level of significance $(\alpha)=5 \%$

Degrees of freedom $(n-k)=25$

\section{Decision Rule}

The decision rule is that if the computed $t_{c}$ value is greater than the tabular $t$ value, we reject the null hypothesis (Ho) and conclude that changes in the independent variables are significant in influencing changes in the dependent variable, otherwise, we accept the null hypothesis.

Therefore, since $t_{c}>t(5.124>2.787)$, we reject the null hypothesis and conclude that the fixed exchange rate system does have a significant positive impact on gross domestic product (or the economy).

\subsection{2 - Hypothesis Two}

Ho; The fixed exchange rate system does not have a significant positive impact on balance of payments (BOP) (i.e the economy). 
$\mathrm{H}_{1}$ : The fixed exchange rate system does have a significant positive impact on balance of payments (i.e the economy).

The researcher has again made use of the ordinary least square method or simple regression based on SPSS to analyze hypothesis two. The aim here is to determine the impact of the fixed exchange rate system on balance of payments.

\section{Presentation of Empirical Results}

Estimated Regression Equation $(\mathrm{ERE})=\mathrm{BOP}=31.800+279.119$ NER(FXD)

Students t-test $\left(\mathrm{t}_{\mathrm{c}}\right)=0.208$

Standard error $(\mathrm{S})=1144.10108$

Coefficient of multiple determination $\left(\mathrm{R}^{2}\right)=0.002$

\section{Interpretation of the results}

The linear function above (BOP $=31.800+279.119$ (NER (FXD) shows the estimated regression function which explains the relationship between the fixed exchange rate system and balance of payments.

The coefficient of the fixed exchange rate (NER FXD) is positive but insignificant (as shown by the $t_{c}$ value of 0.208). The implication of this is that the fixed exchange rate system (NER (FXD)) had a positive but insignificant impact on balance of payments (i.e the economy). The standard error of 1144.10108 implies a positive impact of the fixed exchange rate system on balance of payments.

The coefficient of multiple determination of $\left(\mathrm{R}^{2}\right)$ of 0.002 implies an insignificant positive impact of the fixed exchange rates on balance of payments (or the economy).

\section{Student's t-test}

The student's t-test with $\mathrm{n}-\mathrm{k}$ degrees of freedom at 5\% level of significance in a two-tailed test was employed to calculate the coefficient of the fixed exchange rate system NER (FXD).

The number of observations in the sample $(n)=26$

The number of parameter coefficient $(\mathrm{k})=1$

The level of significance $(\alpha)=5 \%$

Degrees of freedom $(n-k)=25$

\section{Decision rule}

The decision rule is that if the computed $t_{c}$ value is greater the tabular $t$ value, we reject the null hypothesis and conclude that variations in the independent variable are significant in influencing changes in the dependent variable, otherwise we accept the null hypothesis.

Therefore, since $t_{c}<t($ ie $0.208<2.787)$ the test statistic falls within the acceptance region of the null hypothesis. The null hypothesis is therefore accepted with the conclusion that the fixed exchange rate system does not have a significant positive impact on balance of payments (ie the economy).

\subsubsection{Hypothesis Three}

$\mathrm{H}_{\mathrm{o}}$ : The flexible exchange rate system does not have a positive impact on gross domestic product (GDP), (ie the economy),

$\mathrm{H}_{\mathrm{i}}$ : The flexible exchange rate system does have a positive impact on gross domestic product (GDP), (ie the economy)

The researcher has again employed the ordinary least square method or simple regression method using the statistical package for social science (SPSS) computer software to test hypothesis three. The aim of this test is to determine the impact of the flexible exchange rate system on gross domestic product (i.e the economy) during the period Nigeria adopted flexible exchange rates (1986 - 2007).

\section{Presentation of Empirical Results.}

Estimated Regression Equation $(\mathrm{ERE})=\mathrm{GDP}=-592333.766+94681.107$ NER $($ FLEX)

Students' $t$-test $\left(\mathrm{t}_{\mathrm{c}}\right)=6.624$

Standard error $(\mathrm{S})=3541014.298$

Coefficient of multiple determination $\left(\mathrm{R}^{2}\right)=0.687$

\section{Interpretation of the results}

The linear function above (GDP $=-592333.766+94681.107$ NER (FLEX) shows the estimated regression function and results of other items to be estimated. This function implies that a $1.00 \%$ change in the flexible exchange rate (NER (FLEX) will lead to a $1561.418 \%$ change in gross domestic product. 
The coefficient of multiple determinations $\left(\mathrm{R}^{2}\right)$ shows that about $68 \%$ of variations in GDP are explained by changes in the flexible exchange rates. The coefficient of the flexible exchange rate system (NER (FLEX) is positive and statistically significant $\left(\mathrm{t}_{\mathrm{c}}=6.624\right)$. The implication of this is that the flexible exchange rate system has had a significant positive impact on gross domestic product (i.e the economy) within this period.

\section{Student's t-test}

The coefficient of NER (FLEX) (i.e the flexible exchange rate) was calculated using the student's t-test with $n-k$ degrees of freedom at $5 \%$ level of significance in a two-tailed test.

The number of observations in the sample $(\mathrm{n})=22$

The number of parameter coefficient $(\mathrm{k})=1$

The level of significance $(\alpha)=5 \%$

Degrees of freedom $(n-k)=21$

\section{Decision Rule}

The decision rule is that if the computed $t_{c}$ value is greater than the tabular $t$ value, we reject the null hypothesis and accept the alternative hypothesis.

Therefore, since $t_{c}>t$ (i.e $6.624>2.831$ ) we reject the null hypothesis. The conclusion is therefore that the flexible exchange rate system does have a significant positive impact on gross domestic product (i.e the economy).

\subsubsection{Hypothesis Four}

$\mathrm{H}_{0}$ : The flexible exchange rate system does not have a positive impact on balance of payments (BOP).

$\mathrm{H}_{1}$ : The flexible exchange rate system does have a positive impact on balance of payments.

The ordinary least square method also known as the simple regression method using the (SPSS) computer software has been employed by the researcher to test hypothesis four. The aim of this test is determine the impact of the flexible exchange rate system on balance of payments (and by implication, the economy) during this period (1986-2007).

\section{Presentation of Empirical Results}

Estimated Regression Equation $(\mathrm{ERE})=\mathrm{BOP}=-1550.104+(-2916.052)$ NER $($ FLEX).

Students t-test $\left(\mathrm{t}_{\mathrm{c}}\right)-0.816$

Standard error $(\mathrm{S})=885863.8106$

Coefficient of multiple determination $\left(\mathrm{R}^{2}\right)=0.032$

\section{Interpretation of the Results}

The linear function above $(B O P=-1550.104+(-2916.052)$ NER (FLEX) shows the estimated regression function and other items to be estimated. This function implies that a $1.00 \%$ change in the flexible exchange rate will lead to a $(-2916.052) \%$ change in balance of payments.

The coefficient of multiple determination shows that less than $1 \%$ changes in balance of payments are explained by changes in the flexible exchange rates (NER(FLEX)). The coefficient of the flexible exchange rate system (NER (FLEX)) is negative and statistically insignificant (as shown by $t_{c}-0.816$ ). The implication of this is that the flexible exchange rate system has had an insignificant negative impact on balance of payments (i.e the economy) within this period.

\section{Student's t-test}

The coefficient of NER (Flex) was calculated using the student's t-test with n-k degrees of freedom at $5 \%$ level of significance in a two-tailed test.

The number of observations in the sample $(n)=22$

The number of parameter coefficient $(\mathrm{k})=1$

The level of significance $(\alpha)=5 \%$

Degrees of freedom $(n-k)=21$

\section{Decision Rule}

The decision rule is that if the computed $t_{c}$ value is greater than the tabular $t$ value, we reject the null hypothesis and accept the alternative hypothesis. If not, we accept the null hypothesis. Therefore, since the $t_{c}<t$ (i.e- $0.816<2.831$ ), we accept the null hypothesis and conclude that the flexible exchange rate system does not have a significant positive impact on balance of payments (i.e the economy). 


\subsection{Summary}

\section{Chapter Five: Summary, Conclusion And Recommendations}

This study has been undertaken with the aim of comparing the impact the Fixed Exchange Rate System and the Flexible Exchange rate System have had on the Nigerian economy from 1960 - 2007, (the period during which Nigeria has experimented with both systems). The impact these two exchange rate systems have had on Gross Domestic Product (GDP) and Balance of Payments over the period have been considered. Gross Domestic Product and Balance of Payments have been taken as surrogates of the economy.

Chapter one of this study has been devoted to preliminary issues such as introduction, statement of the problem, objectives of the study, research questions, statement of hypothesis, etc. In Chapter two a review of related literature was done. This has been divided into two parts, namely; theoretical review and empirical review. Chapter three has been devoted to methodology. In Chapter IV data collected (which was from secondary sources) has been presented and analysed. Chapter V is a summary of the study

\subsection{Conclusion}

The conclusion from this study has been that the Fixed Exchange Rate System has had a significant positive impact on Gross Domestic Product (GDP)and insignificant positive impact on balance of payments. The Flexible Exchange Rate System on the other hand, has had a significant positive impact on Gross Domestic Product (GDP) and an insignificant negative impact on balance of payments.

\subsection{Recommendations}

The following recommendations are hereby offered:

5.3.1 That the present system of flexible exchange rates be fine-tuned. Available data suggests the preference of fixed exchange rates by developing countries (Nigeria being one). Some form of government intervention is needed especially when the exchange rate of the naira is on the decline. This is known as managed-floating and is embarked upon by the industrialised nations now and then, to shore up the value of their national currencies against other currencies. Japan, China, Russia etc. all engage in this practice!

5.3.2 That the country should explore the possibility of adopting a policy of import-substitution. Heavy dependence on the importation of even non-essential items should be discouraged. The country should look inwards for most of her needs so as to conserve the scarce foreign exchange and improve the country's balance of payments position.

5.3.3 Policies that would encourage domestic production and hence create more employment opportunities and boost incomes of the citizens should be adopted. The private sector and entrepreneurship should be encouraged through government policies and programme to achieve this objective.

5.3.4 That the country should put in place a conducive and enabling environment to attract foreign direct investment into the Nigerian economy. This will reflect positively on the economy in terms of jobs, incomes and a contribution to the Country's Gross Domestic Product.

5.3.5 Policies and programmes aimed at boosting exports should be put in place by government. This will help strengthen the country's balance of payments position.

\section{List Of Appendixes Statistical Package For Social Sciences (Spss) Resuts}

Regression

\section{APPENDIX i}

\begin{tabular}{|l|l|l|l|}
\hline Model & Variables Entered & Variables Removed & Method \\
\hline 1 & NER $^{\text {a }}$ & & Enter \\
\hline
\end{tabular}
a. All requested variables entered.
b. Dependent Variable: GDP

\begin{tabular}{|c|c|c|c|c|}
\hline \multicolumn{5}{|c|}{ Model Summary } \\
\hline Model & $\mathrm{R}$ & R Square & Adjusted R Square & $\begin{array}{l}\text { Std. Error of the } \\
\text { Estimate }\end{array}$ \\
\hline 1 & $.552^{\mathrm{a}}$ & .304 & .275 & 82790.49211 \\
\hline
\end{tabular}




\begin{tabular}{|ll|r|r|r|r|r|}
\hline Model & & Sum of Squares & Df & Mean Square & F & \multicolumn{1}{c|}{ Sig. } \\
\hline 1 & Regression & $7.197 \mathrm{E} 10$ & 1 & $7.197 \mathrm{E} 10$ & 10.500 & \\
& Residual & $1.645 \mathrm{E} 11$ & 24 & $603^{\mathrm{a}}$ \\
& Total & $2.365 \mathrm{E} 11$ & 25 & & \\
& & & & \\
\hline
\end{tabular}

a. Predictors: (Constant), NER

b. Dependent Variable: GDP

Coefficients $^{\mathrm{a}}$

\begin{tabular}{|c|c|c|c|c|c|c|}
\hline \multirow{2}{*}{\multicolumn{2}{|c|}{ Model }} & \multicolumn{2}{|c|}{ Unstandardized Coefficients } & \multirow{2}{*}{$\begin{array}{c}\text { Standardized } \\
\text { Coefficients }\end{array}$} & \multirow[b]{2}{*}{$\mathrm{t}$} & \multirow[b]{2}{*}{ Sig. } \\
\hline & & B & Std. Erro & & & \\
\hline \multirow[t]{2}{*}{1} & (Constant) & -124193.083 & 55117.128 & & -2.253 & .034 \\
\hline & NER & 314025.920 & 96912.111 & .552 & 3.240 & .003 \\
\hline
\end{tabular}

a. Dependent Variable: GDP

\section{Regression}

\section{Appendix Ii}

\begin{tabular}{|c|c|c|c|c|c|c|}
\hline \multicolumn{6}{|c|}{ Variables Entered/Removed ${ }^{b}$} & \\
\hline Model & \multicolumn{2}{|c|}{ Variables Entered } & \multicolumn{2}{|c|}{ Variables Removed } & Method & \\
\hline 1 & \multicolumn{2}{|l|}{$\mathrm{NER}^{\mathrm{a}}$} & & & Enter & \\
\hline \multicolumn{7}{|c|}{ a. All requested variables entered. } \\
\hline \multicolumn{7}{|c|}{ b. Dependent Variable: BOP } \\
\hline \multicolumn{7}{|c|}{ Model Summary } \\
\hline Model & $\mathrm{R}$ & & Square & Adjusted & R Square & $\begin{array}{l}\text { Std. Error of the } \\
\text { Estimate }\end{array}$ \\
\hline 1 & $.043^{\mathrm{a}}$ & & .002 & & -.040 & 1144.10108 \\
\hline
\end{tabular}

ANOVA $^{\mathrm{b}}$

\begin{tabular}{|ll|r|r|r|r|r|}
\hline Model & & Sum of Squares & df & Mean Square & \multicolumn{1}{|c|}{ F } & \multicolumn{1}{c|}{ Sig. } \\
\hline 1 & Regression & 56856.793 & 1 & 56856.793 & .043 & \\
& Residual & $3.142 \mathrm{E} 7$ & 24 & 1308967.291 & & \\
& Total & $3.147 \mathrm{E} 7$ & 25 & & & \\
\hline
\end{tabular}

a. Predictors: (Constant), NER

b. Dependent Variable: BOP

\begin{tabular}{|c|c|c|c|c|c|}
\hline \multicolumn{6}{|l|}{ Coefficients $^{\mathrm{a}}$} \\
\hline \multirow[b]{2}{*}{ Model } & \multicolumn{2}{|c|}{ Unstandardized Coefficients } & $\begin{array}{l}\text { Standardized } \\
\text { Coefficients }\end{array}$ & \multirow[b]{2}{*}{$\mathrm{t}$} & \multirow[b]{2}{*}{ Sig. } \\
\hline & $\mathrm{B}$ & Std. Error & Beta & & \\
\hline (Constant) & 31.800 & 761.676 & & .042 & .967 \\
\hline NER & 279.119 & 1339.251 & .043 & .208 & .837 \\
\hline
\end{tabular}

a. Dependent Variable: BOP

\section{Regression}

\section{APPENDIX iii}

\begin{tabular}{l}
\begin{tabular}{|l|l|l|l|}
\hline Model & Variables Entered & Variables Removed & Method \\
\hline 1 & NER $^{\text {a }}$ & & Enter \\
\hline a. All requested variables entered. \\
b. Dependent Variable: GDP
\end{tabular} \\
\hline
\end{tabular}




\begin{tabular}{|l|r|r|r|c|}
\hline \multicolumn{7}{|c|}{ Model Summary } \\
\hline Model & \multicolumn{1}{|c|}{$\mathrm{R}$} & R Square & Adjusted R Square & $\begin{array}{c}\text { Std. Error of the } \\
\text { Estimate }\end{array}$ \\
\hline 1 & $.824^{\mathrm{a}}$ & .679 & .663 & 59507.76946 \\
\hline
\end{tabular}

a. Predictors: (Constant), NER

ANOVA $^{\mathrm{b}}$

\begin{tabular}{|ll|r|r|r|r|r|}
\hline Model & & Sum of Squares & \multicolumn{1}{|c|}{$\mathrm{df}$} & Mean Square & \multicolumn{1}{c|}{ F } & \multicolumn{1}{c|}{ Sig. } \\
\hline 1 & Regression & $1.496 \mathrm{E} 11$ & 1 & $1.496 \mathrm{E} 11$ & 42.247 & $.000^{\mathrm{a}}$ \\
& Residual & $7.082 \mathrm{E} 10$ & 20 & $3.541 \mathrm{E} 9$ & & \\
& Total & $2.204 \mathrm{E} 11$ & 21 & & & \\
\hline
\end{tabular}

a. Predictors: (Constant), NER

b. Dependent Variable: GDP

Coefficients $^{\mathrm{a}}$

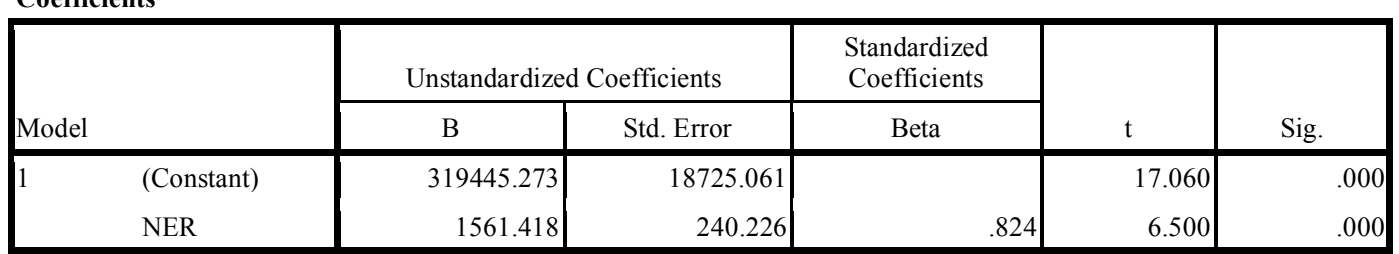

a. Dependent Variable: GDP

\section{APPENDIX iv}

\section{Regression}

Variables Entered/Removed

\begin{tabular}{|l|l|l|l|}
\hline Model & $\begin{array}{c}\text { Variables } \\
\text { Entered }\end{array}$ & $\begin{array}{c}\text { Variables } \\
\text { Removed }\end{array}$ & Method \\
\hline 1 & NER $^{\mathrm{a}}$ & & Enter \\
\hline
\end{tabular}

a. All requested $v$ ariables entered.

b. Dependent Variable: BOP

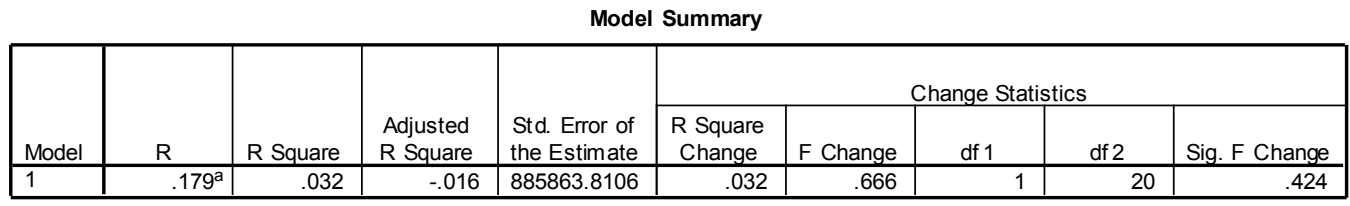

a. Predictors: (Constant), NER

\begin{tabular}{|c|c|c|c|c|c|c|}
\hline \multicolumn{7}{|c|}{ ANOVA $^{b}$} \\
\hline \multicolumn{2}{|c|}{ Model } & $\begin{array}{l}\text { Sum of } \\
\text { Squares }\end{array}$ & df & Mean Square & $\mathrm{F}$ & Sig. \\
\hline \multirow[t]{3}{*}{1} & Regression & $5.2 \mathrm{E}+011$ & 1 & $5.223 \mathrm{E}+011$ & .666 & $.424^{a}$ \\
\hline & Residual & $1.6 \mathrm{E}+013$ & 20 & $7.848 E+011$ & & \\
\hline & Total & $1.6 \mathrm{E}+013$ & 21 & & & \\
\hline
\end{tabular}

a. Predictors: (Constant), NER

b. Dependent Variable: BOP

\section{Coefficients}

\begin{tabular}{|cc|c|c|c|c|r|}
\hline \multirow{2}{*}{ Model } & \multicolumn{2}{|c|}{$\begin{array}{c}\text { Unstandardized } \\
\text { Coeff icients }\end{array}$} & \multicolumn{2}{c|}{$\begin{array}{c}\text { Standardized } \\
\text { Coeff icients }\end{array}$} & & \\
\cline { 3 - 5 } & & $\mathrm{B}$ & Std. Error & Beta & $\mathrm{t}$ & \multicolumn{1}{|c|}{ Sig. } \\
\hline & (Constant) & -1550.104 & 278566.7 & & -.006 & .996 \\
& NER & -2916.052 & 3574.312 & -.179 & -.816 & .424 \\
\hline
\end{tabular}

a. Dependent Variable: BOP 


\section{Bibliography}

[1]. Aczel, A.D. (1999), Complete Business Statistics, Irwin/McGraw-Hill

[2]. Adetoro, S.A (1986), Research Techniques for Projects, Proposal, Reports, Theses and Dissertations. Zaria: Gaskiya Corporation Ltd.

[3]. Aliber, Z. R. (1989), The Handbook of International Financial management, Homewood Illinois: Richard D. Irwin - INC.

[4]. Allen,P.R. and P.B. Kenem(1980), Asset markets and exchange Rates, Cambridge University Press.

[5]. Amacher, R.C and H. H. Ulbrich (1986), Principles of Macro-Economics, Cincinati Ohio: South - Western Publishing Company.

[6]. Ammer, C. and D.S Ammer (1984), Dictionary of Business and Economics (revised and expanded), The Free Press.

[7]. Arnold, R.A.(2005), Macroecnomics, Ohio: Thomson/South-Western.

[8]. Artus,T.R. and G.H.Young(1979),Fixed and Flexible exchange rates: A renewal of the debate, International Monetary Fund Staff papers 26.

[9]. Balassa,B(1964), The purchasing power parity doctrine: A reappraisal, Journal of political Economy,72,584-96.

[10]. Begg, D., S.Fischer and R. Dornbusch (1984) Economics. London: McGraw Hill Books.

[11]. Bigman, D and T. Taya (eds) (1983), Exchange Rate and Trade Instability: Causes, Consequences and Remedies, Ballinger Publishing Company.

[12]. Bilson, J.F.O. (1978), The current experience with floating exchange rates: An appraisal of the monetary approach, American Economic Review, 68 .

[13]. Bilson, J.F.O. (1979), Recent developments in monetary models of exchange rate determination, International Monetary Fund Staff Papers. 26.

[14]. Blandari, J.S and B.H Putnan (eds) (1983), Economic interdependence and flexible Exchange Rates, MIT press.

[15]. Blanchard, O.(2006), Macroeconomics, Pearson Education INC

[16]. Blanchard,O.(2009), Macroeconomics, Pearson/Prentice Hall.

[17]. Brro, R (1978), A Stochastic equilibrium model of an open economy under flexible exchange rates, Quarterly Journal of Economics, 92

[18]. CBN (2005), Statistical Bulletin, Vol. 16. Dec

[19]. CBN (2007), Annual Reports and Statements of Accounts, December, $31^{\text {st }}$

[20]. CBN (2008) Statistical Bulletin, December

[21]. CBN (2009), CBN Briefs (2008-2009).

[22]. Coppock, D. (1978), Some thoughts on the monetary approach to balance of payments theory, Manchester School, 46

[23]. Crockett, A. B and S.M Nsouli (1980) "Exchange Rate Polices for Developing Countries, in Money and Monetary Policy in Less Developed Countries, Coats and Khatkhate (ed) Pergaman Press

[24]. Daily Times, Wednesday 12/1/94

[25]. Davies, O.L and P.L. Goldsmith (eds) (1988), Statistical Methods in Research and Production, UK: Longman Scientific and Technical.

[26]. Doane, D.P and L.E Seward (2008), Essential Statistics in Business and Economics, New York: McGraw-Hill/Irwin

[27]. Dornbusch, R. (1971), Notes on growth and the balance of payments, Canadian Journal of Economics, 4. (389-95).

[28]. Dornbusch, R. (1976), Theory of flexibility exchange regimes and macro economic policy, A Canadian Journal of Economics, 78.

[29]. Dornbusch, R. (1987), Exchange rate economics: 1986, Economic Journal, 97.

[30]. Dornbusch, R. S. Fisher (1980), Exchange rates and the current account, American Economic Review, 70

[31]. Dreyer, J.S; G.Haberer and T.D. Willelt (eds) (1982), The International Monetary System: A Time of Turbulence, American Enterprise Intitute for Public Policy Research, Washington.

[32]. Driskill, R.A. (1981), Exchange rate dynamics: An empirical investigation, Journal of Political Economy, 8

[33]. Duck, W. And Zis, G. (1978), World inflation, the demand for money and fixed exchange rates, Scottish Journal of Political Economy, 25.

[34]. Dun, R.M.J. (1983), The many disappointments of flexible exchange rates, Essays in International Finance No. 154, Princeton: Princeton University press.

[35]. Edwards, S. (1983), Floating, exchange rates, expectations and new information, Journal of Monetary Economics, 11.

[36]. Frank, H and S.C. Althoen (1994), Statistics (concepts and applications),UK: Cambridge University Press.

[37]. Frankel, J.A (1981), Flexible exchange rates, prices and the role of "news": Lessons from the 1970s, Journal of Political Economy, 89.

[38]. Frankel, J.A (ed) (1983), Exchange Rates and International Macroeconomics, the University of Chicago Press.

[39]. Frankel, J.A (1971), A theory of money, trade and balance of payments in a model of accumulation, Journal of International Economics, 1.

[40]. Frankel, J.A and C. Clements (1981), Exchange rates in the 1920s: A monetary approach, in Flanders, M and R. Razin (eds), Development in an inflationary world, A Cademic Press.

[41]. Frankel, J.A and H.G. Johnson (eds) (1976) The Monetary Approach to Balance of Payments, Allen and Unwin.

[42]. Frankel, J.A and H.G. Johnson (eds) (1978), The Economics of Exchange Rates, Addison-Wesley publishing Company.

[43]. Frankel, J.A and M.L. Musa (1985), Exchange rates and the balance of payments in Jones and Kenen (1985).

[44]. Friedman, M. (1953), The case for flexible rates, in Essays in positive Economics, University of Chicago press.

[45]. Gailliot, H.J. (1970), Purchasing Power parity as an explanation of long-term changes in exchange rates, Journal of money, credit and banking, 11 .

[46]. Genberg, H. (1978), Purchasing power parity under fixed and flexible exchange rates, Journal of International Economics, 8 .

[47]. Gujarati,D.N. and Sangeetha(2007), Basic Econometrics, New Delhi: Tata McGraw -Hill Publishing company Limited.

[48]. Hahn, F.H. (1977), The monetary approach to the balance of payments, Journal of International Economics, 7.

[49]. Heller, H.R. (1977), Choosing an exchange rate system, Finance and Development, 14.

[50]. Herin, J.; Lindbeck, A. And Myhrman, J. (1977), Flexible Exchange Rates and Stabilisation Policy, Macmillan

[51]. Hill, C. N. L. (2005), International Business (Competing in the Global Market Place), McGraw -Hill.

[52]. Hooke, A.W. (ed) (1983) Exchange Rate Regime and Policy Interdependence, International Monetary Fund.

[53]. IMF (1977), The Monetary Approach to the Balance of payments, International Monetary Fund.

[54]. IMF, Annual Report 1991

[55]. IMF (1984), Exchange rate volatility and world trade, IMF Occasional paper, 28

[56]. IMF (1984) "Exchange Rate System; Lessons of the past and options for the future, Occasional paper July 30.

[57]. Jhingan, M. L. (2003), Advanced Economic Theory, Delhi: Vrinda Publishers (p) Ltd.

[58]. Jhingan, M. L. (2004), Monetary Economics, Delhi: Vrinda Publications (p) Ltd. (2005) 
[59]. Johnson, H.G. (1977), Money, balance of payments theory and the international monetary problem, Essays in International Finance, No. 124, Princeton University.

[60]. Kaffka, A. (1978), The new exchange rate regime and the developing countrie, Journal of Finance, 33.

[61]. Keller, G and B. Warrack (1999), Statistics for Management and Economics, USA: Brooks/Cole Publishing Company.

[62]. Kindleberger, C.P. (1973), International Economics, Richard D. Irwin INC.

[63]. Laffer, A.B. (1973), Two arguments for fixed rates, in Johnson, H.G. and Swoboda, A.K. (eds), The Economics of Common Currencies, London: Allen and Unwin.

[64]. Leipziger, D.M. (1977), An essay on floating exchange rates: developing Countries concerns, Malayan Bank Economic Review, 13.

[65]. Lewis, A. (1979), The LDCs and stable exchange rates, Third World Quarterly, 1.

[66]. Lipsey, R. G. (2007), An Introduction to Positive Economics, ELBS and Weidenffeld and Nicolson.

[67]. Lipsey, R.G. and K.A Chrystal (2004), Economics, Oxford University Press.

[68]. McGown, K.L (1970), Marketing Research, Text and Cases, Cambridge Massachusetts: Wintrop publishers Inc.

[69]. Mundell, R.A. (1968), International Economics, Macmillan.

[70]. Mussa, M. (1974), A Monetary Approach to balance of payments analysis, Journal of money, credit and banking, 6.

[71]. Mustapha, R. S and B. L. Fabunmi (1990), Finance of International Trade, Lagos: F\&A Publishers limited.

[72]. Obstfeld, M. (1985), Floating exchange rates: Experience and prospects, Brookings papers on Economic Activity, No. 2.

[73]. O'Connor, D.J. and A. T. T. Buesco (1990), International Dimensions of Financial Management, Macmillan Publishing Company Ltd.

[74]. Okpara, G. C. (2006), Monetary Policy Shocks and EconometricAnalysis of Nigerian Experience, Nigerian Journal of Banking and Finance vol $6 . \quad 2003$ - 2006 CECTA Nigeria Limited.

[75]. Onwumere, J.U.J. (2009), Business and Economic Research Methods, Enugu: Vougasen Limited.

[76]. Osuala, E.C. (2005), Introduction to Research Methodology, Enugu: Cheston Agency Limited.

[77]. Schiller,B.R.(2006), The Micro Economic Today, McGraw- Hill/Irwin.(429-442).

[78]. Schiller,B.R.(2003), The Economy Today, McGraw-Hill/Irwin.

[79]. Solmon, L.C (1980), Macro-Economics, Addison-Wesley Publishing Company.

[80]. Thorn, R. S. (1976), Introduction to Money and Banking, New York: Harper and Row.

[81]. Todaro, M.P. and S.C. Smith (2009), Economic Development, Addison Wesley

[82]. Triffin, R. (1960), Gold and the Dollar crisis, Yale University press.

[83]. www.cenbank.org, accessed 12.4.2011.

[84]. Williamson, J. (1983), The Exchange Rate System, Institute for International Economics, Washington.

[85]. Williamson, J. (1982), A survey of the literature on the optimal peg, Journal of Development Economics, 11.

[86]. Wilson, C.A. (1979), Anticipated shocks and exchange rate dynamics, Journal of Political Economy, 87.

[87]. Yomere, G.O. and B.A. Agbonifoh (1999), Research Methodology in the Social Sciences and Education, Benin City: Centre Consultants Nigeria Limited.

[88]. Zis,G., R.Vanbel, S.Baker, T. Hitiris and N. Peera (1984), International Economics, London: Longman.

[89]. Zis, G. (1983), Exchange rate fluctuations 1973-82, National Westminister Bank Quarterly Review. 